\title{
MASJID TUA SHIRATHAL MUSTAQIEM SAMARINDA: Fenomena Dahsyatnya Kekuatan Spiritual
}

\section{The Old Mosque of Shirathal Mustaqiem in Samarinda: The amazing fact of spiritual power}

\author{
Muhammad As'ad \\ Balai Litbang Agama Makassar \\ Alamat: Jl. AP Pettarani No 72 Makassar \\ Email: malitbang@yohoo.com
}

Naskah diterima tanggal 19 Juli 2013. Naskah direvisi tanggal 31 Juli 2013. Naskah disetujui tanggal 15 Agustus 2013

\begin{abstract}
Abstrak
Kota Samarnda (Samarinda Seberang) adalah koloni orang Bugis dari Sulawesi Selatan pada masa dahulu, sebagai hadiah dari kerajaan Kutai Kartanegara Negara di Kalimantan Timur, dan menjadi bahagian dari padanya. Agama Islam berkembang di daerah ini sejak dahu dan meninggalkan tinggalan budaya material, salah satu di antaranya ialah Masjid Sutathal Mustaqiem Samarinda. Masjid tua ini yang letaknya di Samarida Seberang dan berkonstruksi kayu merupakan cagar budaya yang dilindungi oleh Pemerintah, dijaga kelestariannya. Meskipun merupakan tinggalan budaya yang harus dipelihara keasliannya, tetapi secara parsial terjadi perubahan atau penggantian yang esensial, seperti pada kemuncaknya, dan material yang diganti ini tidak terpelihara lagi. Masjid Sirathal Mustaqiem Samarinda tetap difungsikan oleh umat Islam di Samarinda Seberang sebagaimana masjid-masjid lainnya, untuk ibadah, dakwah, pendidikan, dan sosial kemasyarakat, meskipun di antaranya masih terbatas. Untuk kepentingan itu, masjid menyediakan sarana-sarana ledinian yang dibutuhkan.
\end{abstract}

Kata kunci: Kota Samarinda, Masjid Shirathal Musiaqiem, pusat ibadah

\begin{abstract}
The Samarinda city in ancient time was part of Kutai Kartanegara Kingdom and located in East Kalimantan. The city was then presented by the King to the colony of buginese from South Sulawesi. Islam has well devopped in this region long time ago and left several cultural materials, one of them is Shiratal Mustaqiem mosque in Samarinda Seberang. The old mosque is in wooden construction, preseved and protected by government. Although its originality is to be preserved, some parts of its have been modified, for example, its top. This mosque, as the other moques, has facilities for several activities like prayers, proseletyzers, education, and limited social works.
\end{abstract}

Keywords: Samarinda, Masjid Sirathal Musiaqiem, prayers.

\section{PENDAHULUAN}

$\mathrm{M}$ asjid merupakan bangunan khas yang menjadi simbol Islam dan sebagai produk Budaya masyarakat Indonesia yang heterogen. Masjid di Indoneisa tampak berbeda dengan masjid-masjid yang berada di wilayah Timur-Tengah. Atap masjid-masjid kuno di Indonesia tidaklah mengambil bentuk kubah, tapi mengambil bentuk atap tumpang, ada yang bertingkat dua (Agung Cirebon), bertingkat empat (Masjid Kedato Ternate), dan lima tingkat (Masjid
Agung Banten). Mengenai bentuk tumpang pada atap masjid-masjid kuno di Nusantara (Pijper, 1984: 14), berpandangan bahwa bentuk tumpang tersebut mungkin berasal dari bentuk meru pada masa Hindu-Jawa.

Hal tersebut tidaklah mengherankan karena sebelum kedatangan Islam di Nusantara, masyarakat Indonesia (utamanya di Pulau Jawa) menganut ajaran Hindu-Buddha yang masih menyisakan tinggalan budaya material. Menara Masjid Agung Kudus, misalnya, menunjukkan struktur bangunan yang mirip dengan bangunan kulkul di Bali atau 
candi Hindu di Jawa Timur (Pijper, 1984: 66).

Bangunan-bangunan masjid kuno yang bertahan sampai saat ini dan menjadi benda cagar budaya pada umumnya berkonstruksi batu atau batu bata yang tahan lama. Banyak kerajaan-kerajaan Islam yang tercatat sejak dahulu hanya menjadi catatan sejarah yang dapat dibaca oleh generasi pelanjutnya. Tidak meninggalkan bukti material berupa masjid tua, karena bangunan masjidnya tidak tahan lama, misalnya konstruksinya dari kayu yang mudah lapuk.

Berbeda dengan masjid Shirathal Mustaqiem Samarinda (SMS), meskipun berkonstruksi kayu tetapi tetap berdiri kokoh sampai saat ini. Hal ini merupakan fenomena material yang memerlukan perhatian. Dengan demikian perlu pengkajian, bagaimana morfologi struktur bangunan masjid ini.

Penelitian ini merupakan penelitian deskriptif kualitatif. Data dan informasi diperoleh melalui, observasi, wawancara, dan kajian pustaka. Data kepustakaan dikumpulkan dengan menelaah sumber-sumber tertulis yang relevan. Analisis data yang dilakukan mencakup analisis morfologi dan bahan, dimana variabel-variabel yang diamati mencakup, antara lain: bagian kaki, tubuh, dan atap, serta bahan apa yang digunakan. Analisis kontekstual, mengamati lingkungan sekitarnya, termasuk halaman bangunan, pagar keliling, dan bangunan di sekitarnya.

Masjid-masjid kuno menjadi perhatian di antara pakar. Pada tahun 1916, Van Ronkel meneliti masjid-masjid kuno di Jakarta. Sedangkan bangunan masjid di Kudus dan Sendang Duwur, Lamongan digarap oleh Bosch. Dari hasil pengamatannya, ia berkesimpulan bahwa tinggalan masjid di kedua daerah tersebut menunjukkan corak seni bangunan dan seni hias dari masa peralihan (Tjandrasasmita, 2009: 18).

Pijper, setelah meneliti sejumlah menara dan masjid kuno di Indonesia, mengajukan pendapat bahwa masjid-masjid kuno tersebut umumnya tidak memiliki menara. Menara masjid Kudus sebenarnya bukanlah sebuah menara pada awalnya, melainkan sebuah bangunan Jawa-Hindu yang dipakai dan disesuaikan kegunaannya sekarang sebagai tempat kulkul. Ia juga mengemukakan enam ciri masjidmasjid kuno di Indonesia. Atas dasar ciri-ciri tersebut, Pijper juga berpendapat bahwa bentuk masjid-masjid kuno tersebut merupakan tradisi asli yang diterima untuk keperluan peribadatan setempat, bukan bentuk yang datang dari luar (Tjandrasasmita, 2009: 20).

Selain para peneliti asing, terdapat pula peneliti Indonesia yang mengkaji objek serupa. Hasan Muarif Ambary (2001) meneliti kepurbakalaan masjid Panjunan di Cirebon di dalam skripsinya di tahun 1967. Pada tahun-tahun selanjutnya bermunculan skripsi-skripsi yang juga mengkaji masjid-masjid kuno nusantara tersebut dari berbagai aspek, mencakup segi arsitektural maupun sosial. Antara tahun 1976-1995, tercatat setidaknya 26 skripsi di Jurusan Arkeologi Universitas Indonesia maupun Universitas Gadjah Mada yang mengkaji masjid-masjid kuno dalam berbagai tinjauan (Tjandrasasmita, 2009).

Tim peneliti Badan Litbang Agama Jakarta (1999) telah melakukan penelitian terkait masjid kuno di Indonesia, Penelitian ini membahas sejarah pembangunan masjid dan perkembangan Islam pada masanya. Hal ini serupa dengan tulisan Abdul Baqir Zein (1999) yang juga mengulas tentang sejarah pembangunan masjid dan sejarah perjuangan orang-orang yang terkait dengan pengembangan Islam tempat masjid itu berada. Pada tahun 1984 Di Sulawesi Selatan (termasuk Sulawesi Barat sekarang), tim peneliti Balai Litbang Agama Makassar (1984) telah melakukan penelitian tentang masjid, hanya saja penelitian ini hanya mengungkap profil masjid serta benda-benda bersejarah lainnya seperti makam, artefak dan lain sebagainya.

\section{PEMBAHASAN}

\section{Kota Samarinda sebagai Koloni Orang Bugis}

Kota Samarinda yang ditetapkan hari jadinya tanggal 21 Januari 1668 adalah ibukota Provinsi Kalimantan Timur. Cikal bakal kota ini adalah kedatangan migran Bugis dari Kerajaan Wajo, Sulawesi Selatan ke Kerajaan Kutai. La Mohan Daeng Mangkona, seorang bangsawan Kerajaan Wajo bersama pengikutnya menghadap pada Raja Kuta Kartanegara, Pangerang Dipati Mojo Kesumo (1650-1686) pada tahun 1668 untuk meminta izin bertempat tinggal pada kerajaan ini. Atas kemurahan raja Kutai tersebut, permintaan migran Bugis ini dikabulkan dengan syarat bersedia membantu Kerajaan Kutai, terutama dalam mengahadapi musuh.

Atas jasa-jasa La Mohan Daeng Makona bersama pengikutnya mengusir bajak laut yang berasal dari Solok Pilipina, maka pada tahun 1672 
mereka dianugerahi tanah di Samarinda Seberang dengan hak otonom untuk memerintah daerahnya sendiri. Legitimasi hak otonom ini ditandai dengan pemberian gelar Pua' Ado oleh Raja Kutai Kartanegara kepada La Mohan Daeng Mangkona selaku pemimpin di Samarinda Seberang. Gelar ini berlangsung sesudahnya dan tercatat dalam sejarah Kota Samarinda, mulai dari La Mohan Daeng Mangkona sebagai Pua' Ado I masyarakat di Samarinda Seberang dipimpin oleh sembilan orang bergelar Pua' Ado, dan Pua' Ado IX atau terakhir adalah Puanna Rappe Daeng Pesuro (1861-1867).

Di bawah kepemimpinan Pua' Ado ini, Samarinda Seberang mengalami perkembangan yang pesat dari tahun ke tahun dengan kedatangan migran dari berbagai daerah. Keberadaan orangorang Bugis yang diberi kekuasaan otonom di Samarinda Seberang mencatatkan berbagai prestasi dan kemajuan. Kemajuan ini mengkhawatirkan Penjajah Belanda yang berkuasa di Kerajaan Kutai Kartanegara sejak kekalahannya dan rajanya bernama Sultan Muhammad Salahoeddin menanda tangani suatu perjanjian pada tanggal 11 Oktober 1844.

Pada era kemerdekaan, tahun 1960 terjadi perubahan struktur pemerintahan di Kalimantan Timur. Pada tanggal 21 Januari 1960 dalam suatu sidang khusus DPRD Daerah Istimewa Kutai di Tenggarong dilangsungkan upacara penandatanganan naskah serah terima wilayah Kotapraja Samarinda kepada Kepala Daerah Kotapraja Samarinda yang pertama Soedjono AJ. Peristiwa ini menandai terbentuknya Kotapraja Samarinda terpisah dari Kabupaten Kutai dan penghapusan Daerah Istimewa Kutai (Syarifuddin HR dkk, 2003: 103).

Untuk kelengkapan Pemerintahan pada tahun 1962 dibentuk DPRD Peralihan. Sebagai ketuanya ditunjuk Letkol Ngoedio, Bc.Hk. yang saat itu juga menjabat sebagai walikota Kotapraja Samarinda. Rangkap jabatan ini berlangsung sampai tahun 1965, yaitu dalam sidang khusus DPRD Peralihan. Dalam sidang khusus ini, terjadi peristiwa penting, yaitu serah terima jabatan ketua DPRD Peralihan dari Ngoedio, Bc.Hk. kepada wakilnya Bustanil Hn; dan terdapat keputusan penting, yaitu perubahan nama Kotapraja samarinda menjadi Kotamadya Samarinda (Syarifuddin HR dkk, 2003: 106).

\section{Masjid SMS (Shirathal Mustaqiem : ) Sejarah Berdirinya}

\section{Gambar 1. Masjid Shirathal Mustaqiem}

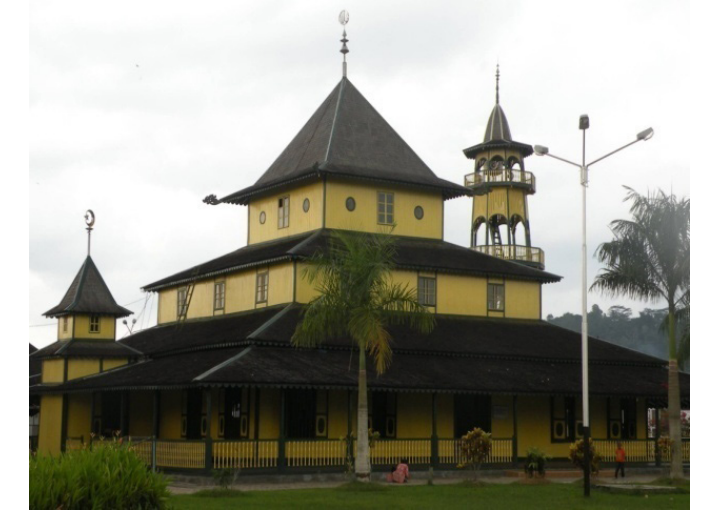

Sumber : Dokumen Pengurus Masjid SMS, 2012

Berdirinya masjid SMS tidak dapat dilepaskan dari kedatangan di samarinda Seberang seorang pedagang muslim dari Pontianak, Kalimantan Barat bernama Said Abdurrahman Assegaf. Meskipun kedatangannya di Kerajaan Kutai Kartanegara untuk berdagang, namun karena ia termasuk tokoh agama Islam, ia berusaha mengemban tanggung jawab untuk mengembangkan Islam dan memilih Samarinda Seberang sebagai tempat tinggalnya.

Informasi tentang ketekunan dan ketaatan dalam menjalankan syariat Islam dan ketokohan dalam masyarakat yang dimiliki Said Abdurrahman Assegaf diketahui dengan jelas oleh Sultan Kutai Aji Muhammad Sulaiman, sehingga mengangkatnya sebagai Kepala Adat dan Agama di Samarinda Seberang pada tahun 1880. Karena ia juga orang kaya raya maka diberi gelar Pangeran Bendahara (Tasa dkk, 2004: 25). Jabatan yang diembankan di atas pundaknya itu sangat mendukung upayanya untuk mengembangkan agama Islam yang bermula dari Samarinda Seberang. Pengembangan Islam dimulai dan berpusat di masjid, karena itu yang pertama diusahakan adalah pembangunan masjid. Untuk merealisasikan pembangunan suatu masjid, yang pertama dipertimbangkan adalah tempat atau lokasi yang strategis kemudian penyediaan bahan bangunan dan selanjutnya peroses pembangunannya.

Di Samarinda Seberang saat itu terdapat sebidang tanah yang dipergunakan sebagai pusat kegiatan kemaksiatan. Pada siang hari dipakai sebagai arena sabung ayam; pada malam hari sebagai arena judi dadu; dan dikenal masyarakat sebagai lokasi tempat beredarnya minuman keras. Sebagai 
Kepala Adat dan Agama, Pangeran Bendahara bersama tokoh masyarakat lainnya berunding untuk mencari jalan keluar dari penyakit masyarakat itu. Pangeran Bendahara mengusulkan suatu pilihan tepat yang disetujui oleh para tokoh masyarakat, yaitu memilih arena judi dan sabung ayat tersebut sebagai lokasi pembangunan masjid.

Selanjutnya dikemukakan, pada tahun 1881 dilakukanlah upaya untuk membangun sebuah masjid. Langkah awal yang dilakukan tentunya adalah sosialisasi kepada masyarakat tentang rencana pemanfaatan lokasi judi dan sabung ayam untuk pembanguanan masjid yang dibutuhkan oleh umat Islam. Tantangan utama yang dihadapi pasti dari pihak-pihak yang diuntungkan oleh kegiatan yang bertentangan dengan agama Islam itu. Akan tetapi upaya penyadaran yang dilakukan dengan bijak membuahkan hasil, da'wah yang menjelaskan secara arif keharaman dan bahaya serta kerusakan yang diakibatkan kebiasaan-kebiasaan buruk itu menyadarkan mereka, bahkan ikut berpartisipasi dan bergotong royong dalam pembangunan masjid itu.

Arsitektur masjid yang disepakati adalah bangunan yang ditopang oleh empat tiang utama (sokoguru) pada bagian tengahnya. Karena itu yang mula-mula dipersiapkan adalah keempat tiang utama itu. Tampilnya para tokoh adat dan agama pada barisan depan pembangunan masjid sebagai panutan menggelorakan semangat kegotong royongan masyarakat. Keempat tiang utama masjid yang berdiameter 30-60 cm disumbangakan oleh para kepala adat saat itu, yaitu: Pangeran Bendahara berupa pohon ulin dari Gunung Dondang Samboja; Kapitan Jaya berupa pohon ulin dari Loa Haur (Gunung Lipan); Petta Loloncong berupa pohon Ulin dari Gunung Salo Tireng; dan Usulonna berupa pohon Ulin dari Karang Mumus.

Pada tahun 1881, 4 tiang utama (soko guru) mulai dipancang dan pembangunan gotong royong mulai dilaksanakan. Ada ceritera menarik yang berbau supra natural di balik pemancangan soko guru Masjid itu. Keritera ini dituturkan secara lisan. Upaya pemancangan tiang soko guru yang besar dan tinggi itu dilakukan secara beramai-ramai namun tidak berhasil. Selanjutnya tanpa ada orang yang menyaksikannya, pada malam harinya keempat tiang soko guru itu telah dipancangkan dengan kokoh di tempatnya oleh seorang nenek misterius. Tidak seorang pun juga yang mengetahui jejak sang nenek misterius setelah terpacang keempat tiang utama masjid (Tasa dkk, 2004: 28 - 31).

\section{Tata Letak Situs Masjid SMS}

Masjid SMS yang merupakan masjid tua bersejarah yang dilindungi oleh Pemerintah, berada di Kelurahan Masjid, Kecamatan Samarida Seberang, Kota Samarinda. Masjid ini terletak di tepi sungai Mahakam pada simpang tiga jalan Pangeran Bendahara dan jalan Monginsidi (Jl. Mas Penghulu). Untuk mencapai situs masjid ini dari pusat Kota Samarinda melalui dua jalur, yaitu jalur darat lewat jembatan Mahakam ke arah hilir Sungai Mahakam dengan jarak sekitar $5 \mathrm{~km}$; atau jalur sungai Mahakam dengan sampan bermesin dengan perjalanan sekitar 15 menit.

Masjid ini berada pada bilangan perkampungan penduduk. Di sekitarnya berdiri rumah-rumah penduduk yang berjejer menghadap ke jalan. Di sebelah timur masjid yang dahulunya hanya terdapat sungai mahakam, saat ini sudah dibanguni rumah penduduk sampai di atas sungai.

Sekitar 200 meter ke arah selatan terdapat komplek pemakaman yang di dalamnya terdapat makam La Mohan Dg. Mangkona yang sangat berjasa dalam membangun Samarinda Seberang. Ia dikenal sebagai migran Bugis dari Wajo yang diberi kuasa secara otonom oleh Sultan Kutai Kartanegara untuk bertempat tinggal di Samarinda Seberang. makam La Mohan Dg. Mangkona bersama isterinya dan 2 orang lainnya yang diyakini masyarakat sebagai orang dekatnya ditutupi dengan bangunan atau pendopo. Nisan makam-makam ini terbuat dari kayu berukir yang dihiasi dengan iskripsi kaligrafis. Hanya saja inskripsinya sangat sulit terbaca keseluruhannya karena sudah mengalami kerusakan. Makam ini merupakan makam bersejarah dan tercatat sebagai benda cagar budaya yang dilindungi.

\section{Deskripsi Bangunan Mesjid}

Masjid SMS berkonstruksi kayu. Ruang utamanya pada dasarnya berbentuk bujur sangkar dengan ukuran $20 \mathrm{~cm}$ x $20 \mathrm{~cm}$, sehingga luasnya 400 $\mathrm{m} 2$. Ruang utama masjid berbentuk bujur sangkar banyak diketemukan pada masjid-masjid tua. Di Sulawesi Selatan dan Sulawesi Barat, masjid-masjid tua yang masih diketemukan semua ruang utamanya bujur sangkar yaitu Masjid Katangka Gowa (12 m x $12 \mathrm{~m}$ ), Masjid Jami’ Palopo (13 m x $13 \mathrm{~m}$ ), Masjid 
Syekh Abd. Mannan Majene (11,40 m x 11,40 m), dan Masjid Sanrobone Takalar (10,50 m x 10,50 m) (Rahim dan Anwar Sanusi, 2007).

Pada bagian tengah sisi barat masjid dibuat mihrab berbentuk segi empat panjang, yang pada dasarnya berukuran $400 \mathrm{~cm}$ x $270 \mathrm{~cm}$. Pada dinding sebelah barat mihrab dibut rak tertutup (lemari) terbuat dari kayu yang kuat untuk tempat menyimpan barang-barang milik masjid. Pada dinding kedua sisi uatara dan selatan mihrab terdapat masing-masing sebuah jendela. Pada gawang mihrab terdapat ragam hias dan inskripsi yang sangat indah. Bagian atap mihrab masjid ini berbentuk tumpang dua dengan kemuncaknya.

Dengan mempergunakan alat penentu arah merek Lensatic Compass pada mihrabnya, diketahui arah hadap masjid Shiratal Mustaqiem berada pada 270 derajat, yang berarti persis ke arah barat. Hal ini menunjukkan bahwa arah hadap masjid Shirathal Mustaqiem tidak sesuai arah hadap kiblat yang semestinya, yaitu pada sekitar 292 derajat atau 22 derajat barat daya.

Untuk membetulkan arah kiblat masjid ini tidak perlu merubah bangunannya, cukup merubah arah dengan menggeser arah shaf. Menggeser arah shaf-shaf shalat mudah dilakukan dengan membetulkan tataletak karpet yang dipergunakan sebagai alas lantai.

Pada bagian timur masjid terdapat serambi memanjang dari utara ke selatan selurus sisi masjid (20 m) dengan lebar 2,30 m. Serambi ini dibangun bersamaan dengan pembangunan masjid. Dengan penambahan serambi lainnya pada sisi utara dan selatan serta bagian barat selurus mihrab yang lebarnya pada dasarnya $400 \mathrm{~cm}$, maka total badan masjid berukuran $28 \mathrm{~m} \times 27,30 \mathrm{~m}(764,40 \mathrm{~m} 2)$ (Hasil pengukuran lapangan, 2011).

Tiang utama (sokoguru) masjid SMS ada empat buah. Keempat tiang ini yang mula-mula dipancangkan pada awal pembangunan masjid, dan pemancangannya dilakuakan seorang tua misterius. Keempat tiang utama ini melambangkan nilai kegotong royongan masyarakat karena masing-masing disumbangan oleh seorang tokoh masyarakat.

Bagian kaki masjid Shiratal Mustaqiem berupa bangunan kolong yang berdiri di atas tiangtiang kokoh yang masa dahulu tinggi lantainya lebih dua meter dari tanah. Di samping tiang-tiang yang berfungsi sebagai tiang badan masjid, penyanggah bagian atap, juga lantainya ditopang oleh tiang-tiang lainnya yang tidak kurang kuatnya dengan tiangtiang badan masjid.

Meskipun tiang-tiang tersebut terbuat dari kayu ulin yang terkenal kuatnya, namun karena usianya yang sangat tua termakan juga tanah sehingga kondisinya rusak berat, hampir roboh sehingga diadakan renovasi terbatas. Renovasi bagian kaki tidak merubah konstruksi rumah panggung dengan tiang-tiang penyaggahnya, hanya saja tiang-tiang penyanggah itu di bungkus dengan beton bersegi empat. Meskipun masih tetap berupa kolong, namun ketinggiannya dari tanah sekitar satu meter karena bagian bawahnya tertimbun tanah.

Secara sepintas konstruksi bangunan kolong ini tidak tampak dari luar karena halaman atau pelataran di luar bangunan masjid selisihnya dengan lantai serambi masjid hanya $40 \mathrm{~cm}$, yang sedikit lebih rendah $(17 \mathrm{~cm})$ dari lantai ruang utamanya. Dengan demikian tidak memerlukan tangga sebagaimana layaknya bangunan panggung.

Bagian tubuh masjid Shiratal Mustaqiem dideskripsikan mulai dari lantainya yang terbuat dari papan kayu ulin kuat yang dipasang pada balok kayu ulin yang diletakkan melintang di atas balok kayu ulin yang lebih besar yang ditopan oleh tiangtiang kayu ulin yang kuat pada bagian kaki. Papanpapan lantai ini yang ukuran lebarnya rata-rata antara $15 \mathrm{~cm}-18 \mathrm{~cm}$ dan tebalnya lebih $2 \mathrm{~cm}$ pada mulanya di pasak dengan pasak kayu, dan setelah direnovasi pasak-pasak kayu itu diganti dengan paku yang kuat. Untuk keindahan dan kenyamanan, lantai papan ini dilapisi dengan karpet shalat.

Dinding masjid pada keempat sisi luar ruang utama dan mihrab terbuat dari papan-papan kayu yang kuat, ukuran tebanya lebih $2 \mathrm{~cm}$ dan lebarnya antara $10 \mathrm{~cm}-18 \mathrm{~cm}$ atau rata-rata $14 \mathrm{~cm}-15 \mathrm{~cm}$. Papan-papan ini dipasang dari luar pada palang balok-balok kayu bagian dalamnya berbentuk setengah lingkaran dengan ukuran diameternya 20 $\mathrm{cm}$. Papan-papan ini diikat pada palang dengan paskpasak kayu. Palang yang menyangga bagian tengah dinding terdapat tiga buah. Dinding masjid ini tingginya sama ketinggian antara lantai dengan atap lapisan bawah, sekaitar $4 \mathrm{~m}$. Agar dinding kayu ini awet dan untuk keindahannya, dicat dengan cat kayu, bagian dalam berwarna putih dan bagian luar berwarna kuning.

Sebagai pembatas bagian luar (pelataran masjid) dengan serambi masjid dibuat dinding atau pagar dari belahan-belahan kayu setinggi $92 \mathrm{~cm}$. Pagar atau dinding serambi ini terdapat 
pada keempat sisi serambi masjid. Di atas dinding serambi ini terdapat ruang kosong yang luas karena ketinggian lantai serambi dengan atap serambi 265 $\mathrm{cm}$.

Tiang utama (sokoguru) masjid Shiratal Mustaqiem berjumlah 4 buah yang berbentuk segi delapan. Keempat tiang utama yang bagian pangkal berdiameter $60 \mathrm{~cm}$ dan bagian ujung berdiameter $30 \mathrm{~cm}$ disumbangkan oleh kepala-kepala adat saat itu, yaitu: Pangeran Bendahara, Kapitan jaya, Petta Loloncong, dan Usulonna. Tiang utama yang disumbangkan oleh Pangeran Bendahara berupa pohon Ulin dari Gunung Dondang Samboja, disumbangkan oleh Kapitan Jaya adalah pohon Ulin dari Loa Haur; yang disumbangkan oleh Petta Loloncong berupa pohon Ulin dari Gunung Sallo Tireng (Sungai Tiram), dan yang disumbangkan oleh Usulonna adalah pohon Ulin dari Karang Mumus (Tim Penyusun, 2006: 13).

Keempat tiang utama ini berada ditengahtengah ruang utama dan berfungsi sebagai penyanggah atap lapisan atas. Posisi keempat tiang utama ini membentuk bujur sangkar yang bersisi $630 \mathrm{~cm}$. Tiang yang berbentuk segi delapan ini ukurannya pada bagian lantai masjid sekitar 41$43 \mathrm{~cm}$. Dalam sejarah pembangunan masjid ini, keempat tiang utama ini yang mula-mula didirikan oleh seorang orang tua yang misterius.

Pada jarak sekitar 3 meter sebelah luar masing-masing tiang utama ini dipasang tiang-tiang penyanggah atap lapisan kedua yang jumlah 12 buah. Posisi tiang-tiang ini masin-masing membentuk garis lurus sehingga membentuk bujur sangkar yang bersisi 12,30 m. Tiang-tiang ini berbentuk segi empat yang pada bagian lantai berukuran rata-rata sisinya $25 \mathrm{~cm}$.

Pada bagian luar ruang utama terdapat 22 buah tiang berbentuk segi empat yang rata-rata besar sisinya pada bagian lantai masjid berkisar $23 \mathrm{~cm}$. Sebanyak 20 buah dari tiang-tiang bagian luar ini berada pada posisi membentuk garis lurus dengan tiang-tiang bagian dalam ruangan sehingga membentuk bujur sangkar bersisi $20 \mathrm{~m}$. Sebanyak 2 tiang lainnya terpasang di sisi barat masjid pada posisi membentuk mihrab. Tiang-tiang pada sisi luar ruang utama ini berfungsi sebagai penyangga atap lapisan bawah dan berfungsi pula sebagai tempat memasang palang-palang dinding.

Untuk masuk pada ruang utama masjid, melalui tiga pintu yang bentuk dan ukurannya sama, yaitu pintu pada sisi timur pada bagian tengah badan masjid yang lurus dengan mihrab dan pintu sisi utara yang letaknya pada bagian tengah badan masjid dan lurus dengan pintu pada sisi selatan. Ketiga pintu ini lebarnya $170 \mathrm{~cm}$ dan tingginya $230 \mathrm{~cm}$ dengan kuseng balok kayu segi empat yang ukuran sisinya $17 \mathrm{~cm}$. Ketiga pintu ini ditutup dengan daun pintu ganda yang terbuat dari kayu ulin yang tebalnya $5 \mathrm{~cm}$. Daun pintu ganda tidak dipasang pada ensel besi sebagaimana biasanya, tetapi bagian bawah sudut pintu diikat pada ensel kayu berbentuk setengah lingkaran dengan ukuran diameternya $28 \mathrm{~cm}$, dan bagian atasnya terpasang pada balok kayu bersegi empat yang melintang pada bagian atas pintu masuk itu. Untuk pengamanan masjid, daun pintu ini dari dalam dikunci dengan palang kayu dan dari luar dengan slop yang dipasang pada palang besi yang tebal.

Untuk kenyamanan beribadah serta kegiatan lainnya di dalam masjid Shiratal Mustaqiem, konstruksinya memanfaatkan potensi alam dengan fentilasi udara berupa jendela. Melalui jendela ini angin secara bebas memasuki ruang tengah masjid yang dibatasi dengan dinding papan sebagaimana telah dikemukakan. Pada keempat sisi masjid dibuat masing-masing 4 buah jendela, sehingga berjumlah 14 buah jendela. Pada bagian mihrab dibuat 2 buah jendela, masing-masing pada sisi utara (kanan) dan selatan (kiri). Ukuran jendela pada badan masjid rata-rata lebar $120 \mathrm{~cm}$ dan tinggi $165 \mathrm{~cm}$, sedang pada mihrab lebar $110 \mathrm{~cm}$ dan tinggi $165 \mathrm{~cm}$. Posisi jendela, baik pada badan masjid maupun pada mihrab, dari lantai masjid tingginya $65 \mathrm{~cm}$.

Kuseng dari semua jendela terbuat dari balok kayu ulin yang berukuran rata sisinya $15 \mathrm{~cm}$, sehingga sangat kuat. Untuk pengamanan, pada setiap jendela dipasang tralis dari kayu bulat dengan ukuran lingkar $15 \mathrm{~cm}$. Pada masing-masing jendela ruang utama masjid dipasang 7 tralis, dan pada masing-masing jendela mihrab dipasang 6 tralis. Pada masing-masing jendela dipasang daun jendela ganda terbuat dari kayu yang dapat dibuka-tutup.

Bentuk atap masjid SMS bergaya limasan bujur sangkar yang bersusun tiga. Ketiga susun (lapisan) atap dari atas masing masing disokong atau ditopang oleh tiang-tiang masjid seperti telah dikemukakan. Atap paling atas disokong oleh 4 tiang utama bersegi delapan dengan tinggi $15 \mathrm{~m}$; atap lapisan kedua disokong oleh 12 tiang pembantu setinggi $10 \mathrm{~m}$; dan atap lapisan ketiga disokong oleh 22 tiang pembantu yang mengelilingi 12 tiang pembantu ditengah. Bahan atap dari masjid ini adalah kayu yang dibelah-belah tipis dan dipotongpotong (sirap). 
Jarak antara atap lapisan atas dengan atap lapisan tengah lebih satu meter, demikian pula antara atap lapisan tengah dengan atap lapisan bawah. Antara atap lapisan atas dengan atap lapisan tengah pada keempat sisinya terdapat dinding pengaman terbuat dari kayu. Pada masing-masing keempat sisi dinding ini, terdapat sebuah jendela berbentuk segi empat yang berdaun jendela ganda. Daun jendela ini terbuat dari kaca dengan bingkai kayu. Jendela-jendela ini masing-masing diapit oleh loster kaca bundar yang relatif kecil. Jendela-jendela ini dapat berfungsi sebagai pintu masuk dan untuk sirkulasi serta pencahayaan di atas plavon. Pada bagian bawah atap lapisan atas ini terdapat plavon tertutup. Dikatakan tertutup karena tidak terdapat pintu dari bawah untuk masuk ke atasnya. Plafon ini terbuat dari papan kayu yang ditopang oleh balok kayu yang relatif besar. Dengan adanya plafon ini, sirkulasi dan pencahayaan dari jendela dan loster pada atap lapisan atas tidak berfungsi untuk ruang masjid.

Jarak antara atap lapisan tengah dengan atap lapisan bawah pada keempat sisi, juga ditutup dengan dinding kayu sebagai pengaman. Pada masing-masing sisi dinding ini terdapat 3 jendela kaca berbentuk segi empat. Jendela-jendela kaca ini tertutup sehingga hanya berfungsi sebagai pencahayaan, bukan untuk sirkulasi atau jalan masuk udara atau angin.

Puncak atap lapisan atas ditutup dengan kemuncak (mustoko) terbuat dari kayu yang pada ujungnya terdapat bulan bintang. Karena kemuncak ini rusak, bintangnya jatuh diganti dengan bulan bintang lain, dan setelah rusak kena angin maka diganti dengan kemuncak betul-betul lain, bukan lagi bulan bintang tetapi lafzul jalalah.

Tiang kemuncak terbuat dari kayu yang tidak terpakai lagi dan dibiarkan tergeletak, bahkan dijadikan penyangga balok kayu yang tersimpan pada suatu tempat di belakang sebuah bangunan di areal masjid. Tiang kemuncak ini berukuran tinggi $130 \mathrm{~cm}$, garis tengah bagian kaki $25 \mathrm{~cm}$ dan bagian puncak $12 \mathrm{~cm}$.

\section{Bangunan pendukung/Aksesori}

Salah satu bangunan pendukung sekaligus sebagai assesori sebuah masjid yang sangat penting, baik masjid tua maupun masjid baru adalah mimbar. Mimbar sebagai tempat khatib menyampaikan khotbah Jum'at, keberadaannya merupakan keniscayaan.
Mimbar dari masjid Shirathal Mustaqiem merupakan mimbar tua yang ditetapkan sebagai cagar budayabersama masjid yang perlu dipelihara dan dilestarikan. Posisi mimbar dalam ruangan utama cukup jauh dari mihrab atau dinding sebelah barat, yaitu $340 \mathrm{~cm}$. Arsitek mimbar ini sangat indah, terbuat dari kayu pilihan dengan hiasan yang sangat menarik.

Bila mimbar ini dideskripsikan mulai dari bagian kaki, terlihat ukuran kakinya adalah: panjang $244 \mathrm{~cm}$, lebar $104 \mathrm{~cm}$, dan tinggi $18 \mathrm{~cm}$, ukuran badannya panjang $226 \mathrm{~cm}$, lebar $97 \mathrm{~cm}$, dan tinggi $230 \mathrm{~cm}$. Atap mimbar berbentuk limas bersegi empat dengan kemuncak balok berhias.

Salah satu kelengkapan masjid yang penting terutama sebelum dikenal pengeras suara adalah bedug. Masih banyak masjid mempertahankan keberadaan beduk sebagai kelengkapan masid. Setiap masuk waktu shalat lima waktu, beduk dipukul sebagai pertanda, sakaligus sebagai panggilan shalat berjamaah mendahului azan. Masuknya bulan suci Ramadhan biasanya ditandai dengan irama beduk bertalu-talu pada sore hari menjelang malam pada malam Tarawih hari pertama. Demikian pula menjelang pelaksanaan Idul Fitri dan Idul Adha.

Sebagaimana pada masjid-maasjid lainnya, beduk masjid terbuat dari potongan batang kayu bundar yang dilubangi bagian tengahnya sehingga berbentuk silinder. Panjang batang kayu setelah dipotong $216 \mathrm{~cm}$. Pada salah satu ujungnya ditutup dengan kulit sapi yang bila dipukul menimbulkan bunyi keras. Ujung yang dipasangi kulit sapi bergaris tengah $60 \mathrm{~cm}$, sedang ujung yang dibiarkan berlubang bergaris tengah $55 \mathrm{~cm}$. Beduk ini dibuatkan kaki dari kayu setinggi $155 \mathrm{~cm}$ dan diletakkan pada sudut timur laut serambi masjid, tidak jauh dari menara masjid.

Untuk keperluan bersuci, dibuat kolam untuk berwudhu yang berbentuk segi empat panjang. Posisi kolam berwudhu ini pada sisi tenggara masjid atau sebelah selatan menara. Kolam ini tetap dilestarikan meskipun sudah tidak digunakan lagi. Pada saat ini permukaan kolam ini lebih rendah dari pelataran masjid setelah dilakukan penimbunan. Untuk tempat mengambil air wudhu bagi jemaah masjid dibangun tempat berwudhu berupa kolam sistem pancuran. Tempat berwudhu pada areal masjid ini ada dua yaitu pada sisi sebelah utara masjid, dan pada deretan bangunan sebelah barat masjid.

Keberadaan menara masjid SMS erat kaitannya dengan kedatangan seorang saudagar 
berkebangsaan Belanda di Samarinda Seberang bernama Henry Dasen. Ia adalah sosok muallaf yang mempunyai kepedulian yang tinggi terhadap masjid SMS yang dibuktikan dengan kesediaannya membangun menara masjid ini. Henry Dasen, pada tahun 1901, sepuluh tahun setelah peresmian pemakaian masjid Shirathal Mustaqiem yang berbentuk segi delapan, setinggi 21 meter (Tasa dkk. 2004: 33).

Menara masjid ini hanya satu buah terletak pada sisi timur masjid di sebelah selatan pintu masuk serambi dengan jarak $220 \mathrm{~cm}$ dari serambi masjid. Konstruksi menara ini merupakan bangunan dari kayu yang kuat. Karena bangunannya bersegi delapan maka tiangnya ada 8 buah yang berdiri dengan posisi membentuk segi delapan. Tiangtiang ini berbentuk segi empat dengan ukuran 19 $\mathrm{cm}$ x $19 \mathrm{~cm}$. Karena tingginya menara, maka setiap tiang terdiri beberapa tiang yang disambung dengan sistim pasak. Tiang-tiang ini berdiri dengan posisi sedikit miring ke dalam sehingga membentuk satu bangunan yang semakin puncak semakin lebih kecil.

Sebagaimana bangunan masjid, menara ini merupakan bangunan kolong yang dahulu lantai dasarnya tinggi. Dan setelah direnovasi, karena di bawah kolong telah ditimbun maka ketinggiannya sekarang hanya $90 \mathrm{~cm}$ yang untuk menaikinya melalui tangga kayu yang anak tangganya 3 buah. Untuk memperkuat kaki menara ini, tiang pada kolong dibungkus dengan cor beton.

Menara ini terdiri atas 4 lantai dan jarak setiap lantai antara $460 \mathrm{~cm}-480 \mathrm{~cm}$. Untuk menghubungkan setiap lantai terdapat 3 tangga kayu yang tinggi, dengan jumlah anak tangga setiap tangga 12 dan 13 anak tangga. Karena posisi tiang menara miring ke dalam maka luas setiap lantai bervariasi, semakin di bawah semakin luas dan semakin di atas semakin sempit. Lantai satu berukuran $6,50 \mathrm{~m}$ x $6,55 \mathrm{~m}$, lantai dua berukuran $6,10 \mathrm{~m} \times 6,00 \mathrm{~m}$, lantai tiga berukuran $5,10 \mathrm{~m} \times 5,10 \mathrm{~m}$, dan lantai empat berukuran $4,20 \mathrm{~m}$ $\mathrm{x} 4,20 \mathrm{~m}$. Untuk pengamanan setiap lantai dikelilingi dengan pagar atau dinding belahan-belahan kayu.

Atap menara berbentuk segi delapan sesuai model menara dan terbuat dari belahan kayu atau sirap. Model atap menara tumpang yang ditutup dengan kemuncak yang pada puncaknya sekarang terdapat lafzul Jalalah. Jarak antara lantai empat dengan atap sekitar 2,50 m. Lantai empat ini dahulu ditempati muazzin mengumandangkan azan setiap waktu shalat. Karena teknologi pengeras suara telah merambah ke masjid ini, maka lantai empat di tempatkan lost speaker yang mengarah ke berbagai arah.

Untuk pengamanan, pada sekeliling areal masjid dibangun pagar pengaman dan pembatas. Ada 3 jenis pagar yang terpasang pada keempat sisi areal masjid. Pada sisi timur dan selatan yang berbatasan dengan jalan raya dipasang pagar tembok dan besi yang indah, yang padanya terdapat kaligrafi lafzul jalalah dan Muhammad. Ketinggian pagar ini sekitar $175 \mathrm{~cm}$. Pada sisi barat yang berbatasan dengan lahan penduduk dan kuburan dipasang pagar tembok setinggi $170 \mathrm{~cm}$. Sedang pada sisi utara yang berbatasan dengan pemukiman penduduk di pasang pagar belahan-belahan kayu yang tingginya sekitar $200 \mathrm{~cm}$.

Ragam hias/relif untuk mempercantik masjid terdapat pada beberapa tempat, yaitu atap bagian atas, yaitu pada keempat sudutnya terdapat hiasan kayu berukir; pada mimbar masjid, yaitu pada dinding, atap, dan gawang mimbar dan gawang mihrab. Ragam hias pada gawang mimbar dan pada gawang mihrab terdapat inskripsi. Pada gawang mimbar inskripsinya berbunyi laa ilaaha illallah muhammadun rasulullah, 1311. Sedang pada gawang mihrab bertuliskan qaalallahu ta'alaa innamaa ya'muru masaajidallah ..., wakanal faragu ...

\section{Fungsi Masjid}

Sejak diresmikan pemakaiannya pada tahun 1891, masjid SMS tetap dipergunakan sebagai pusat ibadah bagi masyarakat Islam di lingkungannya. Setiap pelaksanaan Shalat Jumat ramai dikunjungi oleh kaum muslim. Dewasa ini para khatib yang membacakan khutbah Jumat telah dijadwal oleh panitia selama setahun.

Pelaksanaan shalat lima waktu berjalan dengan lancar setiap waktu shalat dan diikuti oleh jemaah rata-rata beberapa puluh orang, termasuk jemaah perempuan. Posisi jemaah perempuan di belakang jemaah lelaki atau bagian timur masjid yang dibatasi dengan tirai terbuat dari kayu yang mudah dibuka dan ditutup.

Masjid ini paling ramai dikunjungi oleh jemaah baik laki-laki maupun perempuan pada pelaksanaan shalat Idul Fitri atau Idul Adha. Ruang masjid ditambah dengan serambinya tidak mampu menampung jemaah sehingga ke halaman masjid.

Syiar Islam tampak sekali pada saat memasuki bulan Ramadhan. Pelaksanaan Shalat tarawih 
cukup meriah dihadiri oleh jemaah, laki-laki dan perempuan, orang tua dan anak-anak. Keramaian jemaah menghadiri shalat Subuh jauh lebih disbanding hari-hari di luar bulan Ramadhan. Tradisi turun temurun sebagai ciri khas masjid Shirathal Mustaqiem yang senantiasa terpelihara adalah buka puasa bersama dengan makan nasi bubur (nanre peca: Bugis).

Buka puasa : ala masjid Shiratal Mustaqiem dengan nasi bubur ini berguna sebagai media da'wah. : ini banyak dikunjungi orang luar yang salah satu daya tariknya adalah nasi bubur ini. Momentum Ramadhan dimanfaatkan oleh pengurus masjid untuk kegiatan da'wah Islam dengan mengundang para muballig secara bergilir mengisi ceramah Tarawih setiap malam.

Momentum hari-hari besar Islam senantiasa menjadi perhatian pengurus masjid Shirathal Mustaqiem dan dimanfaatkan untuk syiar dan da'wah Islam. Persiapan yang baik dan penyediaan fasilitas pelaksanaan Shalat Idul sebagai salah satu bukti nyata. Peringatan Maulid dan Peringatan Isra' Mi'raj Nabi Muhammad saw sudah menjadi tradisi sejak dahulu. Tradisi peringatan kedua peristiwa sejarah Nabi ini jelas sekali merupakan budaya dari Bugis (Sulawesi Selatan).

Pada peringatan Maulid Nabi Muhammad saw masyarakat muslim berbondong-bondong menghadirinya dengan membawa penanganan khusus untuk itu, yaitu nasi ketan dan telur berhias. Pada peringatan ini kisah maulid Nabi yang diterjemahkan dalam bahasa daerah Bugis dibaca dengan alunan suara sehingga enak didengar. Pada peringatan Isra' dan Mi'raj Nabi meskipun tidak ada penanganan tersendiri tetap menarik minat masyarakat karena adanya pembacaan kisah Isra' dan Mi'raj yang dikenal dengan Kitta' Meraje' yang juga diterjemahkan dalam bahasa Bugis.

Tradisi peringatan ini telah mengalami perubahan dan pelaksanaannya, sehingga banyak yang hanya menjadi kenangan masa lalu. Pembacaan kisah Maulid dan Isra' Mi'raj Nabi Muhammad saw dengan alunan suara tidak dilakukan lagi, dan sebagai gantinya hanya ceramah agama berkaitan dengan kedua hal itu. Tradisi nasi ketan dan telur berhias untuk peringatan Maulid Nabi kembali ditampilkan lagi pada akhir-akhir ini. Hari bersejarah Islam lainnya yang dahulu tidak ditradisikan dan akhir-akhir ini menjadi perhatian adalah peringatan tahun baru Islam, tanggal 01 Muharram. Khususnya di masjid SMS, peringatan tahun baru Hijriyah diadakan dengan berbagai kegiatan, mulai dari ceramah agama dengan mendatangkan ulama terkenal sampai pelaksanaan berbagai lomba yang Islamya.

Masjid SMS di samping sebagai pusat da'wah Islam sejak dahulu, juga tampil sebagai pusat : Islam. Sejak dahulu sebelum tahun 1950-an pada masjid Shirathal Mustaqiem sudah sering diadakan ceramah-ceramah Islam dan salah seorang ulama yang dikenal masyarakat saat itu bernama $\mathrm{KH}$. Djuhaipa Thalib. Pada saat ini pengajian kitab secara rutin dilakukan setiap Senin malam oleh pimpinan pondok pesantren yang ada di Samarinda Seberang. Pengajian ini diikuti oleh para jemaah masjid dan segenap santri dari pesantren tersebut.

Pendidikan agama non formal bagi anak-anak yang dilakukan pada masjid Shirathal Mustaqiem adalah pengajian dasar al quran yang diadakan di serambi masjid pada setiap sore usai Shalat Ashar. Pada tahun 1952 dirintis pendidikan formal dengan mendirikan madrasah. Perwujudan pendidikan formal lebih tampak sesudahnya. Pada tahun 1956 di Masjid Shirathal Mustaqiem didirikan Madrasah Diniyah Islamiyah (MDI) atas prakarsa Ismail Abdullah, H. Zainuddin Abdullah, dan Baharuddin. Waktu belajar pada madrasah ini, pagi hari (07.3010.00) dan siang hari (14.00-15.30). Mata pelajaran yang diajarkan Tauhid, Fiqih, Bahasa Arab dan ilmu-ilmu Islam lainnya. Tempat belajar yang dipergunakan adalah serambi masjid dengan peralatan sederhana berupa papan tulis dan meja kecil untuk tempat menulis.

Pada saat penelitan ini, pendidikan bagi anak-anak hanya berupa pendidikan non formal, yaitu Taman Pendidikan Al quran yang menempati gedung tersendiri pada areal masjid. Waktu belajar ada yang pagi hari dan ada yang siang hari. Lembaga pendidikan ini belum berbentuk pendidikan formal seperti taman kanak-kanak.

Selain fungsi-fungsi tersebut, di antara masyarakat ada yang memanfaatkan Masjid SMS sebagai tempat melangsungkan perkawinan. Akad nikah dilaksanakan di ruang masjid dan kedua calon penganting masing-masing datang ke masjid dengan rombongannya. Setelah akad nikah, kedua mempelai beserta rombongannya secara bersamasama berangkat ke rumah mempelai wanita.

Untuk mendukung pelaksanaan fungsifungsi tersebut, terutama kenyamanan dalam melaksanakan kegiatan di dalam masjid, diadakan peralatan modern berupa alat elektronik, seperti alat 
pengeras suara, kipas angin berdiri atau tempel, alat pembersih debu karpet, dan jam dinding. Peralatan modern lainnya adalah lampu hias berbagai ukuran, selain untuk penerangan juga untuk menambah keindahan masjid.

\section{PENUTUP}

Masjid Shirathal Mustaqiem yang didirikan sejak tahun 1881 merupakan masjid yang dilindungi sebagai benda cagar budaya. Karenanya harus tetap dipelihara keasliannya sehingga memerlukan pemeliharaan yang baik. Penggantian unsur yang rusak tidak merubah bentuk aslinya, dan unsur yang diganti dipelihara dengan baik dalam suatu penyimpanan tersendiri. Sebagai benda bersejarah dalam perkembangan Islam perlu dipromosikan sebagai objek wisata keagamaan.

Masjid ini secara morfologi masih mempertahankan ciri khas sebagai masjid tua, berarsitektur kayu sehingga merupakan barang langka. Masjid ini tetap mamainkan berbagai fungsi masjid, sebagai pusat ibadah, da'wah, dan pendidikab.

\section{UCAPAN TERIMA KASIH}

Penulis ucapkan kehadirat Allah swt yang telah memberikan rahmat dan hidayah-Nya sehingga tulisan ini dapat terselesaikan dengan baik. Proses yang panjang penulis lalui, mulai dari penelitian lapangan, penulisan hasil penelitian, seminar, dan sampai pada penyusunan artikel benyak pihak yang terlibat di dalamnya. Olehnya itu penulis mengucapkan terima kasih Kepada Kepala Balai Litbang Agama Makassar atas kesempatan dan amanah yang diberikan untuk melakukan penelitian tentang masjid tua di Kota SamarindaKalimantan Timur Terima kasih pula kepada pengurus masjid Shirathal Mustaqiem Samarinda yang telah memberi informasi yang dibutuhkan; H. Zainuddin Abdullah sebagai tokoh agama dan saksi hidup yang banyak berkiprah di masjid ini; dan kepada semua pihak yang telah memberikan bantuan dalam penyususnan artikel ini.

\section{DAFTAR PUSTAKA}

Ambary, Hasan Muarif. 2001. Menemukan Peradaban Jejak Arkeologis dan Historis Islam Indonesia. Jakarta: Logos Wacana Ilmu.

Badan Penelitian dan Pengembangan Agama Departemen Agama RI 1999 Sejarah masjidmasjid Kuno di Indonesia. Jakarta: Badan Litbang Agama.

Badan Pusat Statistik Kota samarinda. 2010. Kota Samarinda dalam Angka 2010. Samarinda BPS Kota Samarinda.

Balai Penelitian Lektur Keagamaan Ujung Pandang, Badan Penelitian dan Pengembangan Agama Departemen Agama RI. 1984. Benda-benda Bersejarah Bercirikan Keagamaan di Sulawesi Selatan. Ujung Pandang: Badan Litbang Agama.

Pijper, G.F. 1984 "Mesjid-Mesjid di Pulau Jawa", dalam: Tudjimah (Penerjemah). Penelitian Tentang Agama Islam di Indonesia 1930-1950, Jakarta: Penerbit UI Press.

Rahim, Ramli dan Anwar Sanusi. 2007. Topologi, Morpologi, dan Tipologi Masjid Tua di Sulawesi Selatan. Makassar: Jurusan Arsitektur Fakultas Teknik Universitas Hasanuddin.

Syarifuddin HR dkk. 2003. Merajuk Kembali Sejarah Kota Samarinda. Samarinda: Pemda Kota Samarinda.

Tasa, Ridwan dkk. 2004. Kilas Sejarah Masjid Shirathal Mustaqiem Samarinda. Samrinda: Pemerintah Kota Samarinda.

Tim Direktori Masjid Bersejarah dan ternama Propinsi Kalimantan Timur. 2006. Masjid Bersejarah \& Ternama di Kalimantan Timur. Samarinda: Kantor Wilayah Departemen Agama Provinsi Kalimanatan Timur.

Tjandrasasmita, Uka. 2009. Arkeologi Islam Nusantara. Jakarta: Kepustakaan Gramedia Populer (KPG).

Zein, Abdul Baqir. 1999. masjid-masjid Bersejarah di Indonesia. Jakarta: Gema Insani Press. 